\title{
TCOM \\ Students as storytellers: mobile-filmmaking to improve student engagement in school science
}

\section{Kaitlyn M. Martin, Lloyd S. Davis and Susan Sandretto}

\begin{abstract}
Student engagement is an important predictor of choosing science-related careers and establishing a scientifically literate society: and, worryingly, it is on the decline internationally. Conceptions of science are strongly affected by school experience, so one strategy is to bring successful science communication strategies to the classroom. Through a project creating short science films on mobile devices, students' engagement greatly increased through collaborative learning and the storytelling process. Teachers were also able to achieve cross-curricular goals between science, technology, and literacy. We argue that empowering adolescents as storytellers, rather than storylisteners, is an effective method to increase engagement with science.
\end{abstract}

Keywords

DOI

Introduction
Public engagement with science and technology; Science education; Visual communication

https://doi.org/10.22323/2.18050204

Submitted: 28th February 2019

Accepted: 16th August 2019

Published: 14th October 2019
International declines in student engagement with science are of significant concern as there is a strong relationship between pursuit of science and science engagement at school [Osborne, Simon and Collins, 2003; Potvin and Hasni, 2014]. Experiences in science classes at school can have a significant impact on engagement with science [Venville et al., 2013; Reinhold, Holzberger and Seidel, 2018]. Studies suggest that learners chose whether to seek a career in science, or not, as adolescents (12 to 16 years old) [Cleaves, 2005; Tai et al., 2006; Lindahl, 2007; Maltese and Tai, 2010] and those who report more positive experience with school science are far more likely to continue to pursue science after this age [Shirazi, 2017]. Strategies to maintain engagement across this transition between primary and secondary schooling are needed as this is the critical age students make choices, knowingly or subconsciously, of what they will pursue in their future.

Focusing on the development of engaging teaching practices and experiences in the science classroom may be the best strategy to encourage students to stay in science 
[Maltese and Tai, 2010] as motivation and interest in science are dependent, in part, on teacher practice [Shirazi, 2017]. Science communication can offer successful engagement strategies to science education to reignite interest [Baram-Tsabari and Osborne, 2015]. Previous research has called this joining-of-forces a third space [Stocklmayer, Rennie and Gilbert, 2010] where formal and informal science education systems work together in order to promote science engagement and literacy [de Vries and van der Sanden, 2016]. Successful informal science communication efforts for adolescents such as those at museums, outreach programmes, and extra-curricular activities tend to remove students from the classroom. While these can offer immense benefit, and spark an interest in science, they do not address the challenges faced by teachers and students inside the classroom where negative views can continue to develop [Cleaves, 2005; Lyons, 2006]. Hence, it is potentially beneficial for science communicators to work with educators to develop in-classroom strategies for improving engagement with science.

Science communication currently exists within many formal education curriculums as a Nature of Science (NoS) learning area. Students are expected to have knowledge of how to conduct, scrutinise, research, and communicate science [Lederman, 2007; Ministry of Education, 2007]. It has been found that an understanding of the nature of science supports scientific learning, encourages appropriate use of scientific knowledge, and enhances appreciation of science as a social human activity [Driver et al., 1996]. While NoS is meant to provide such experiences and appreciations, this is a notoriously difficult area for educators to teach because they often have not practised as scientists themselves [Hipkins, 2012]. In order to help meet NoS curriculum goals previous strategies have had students create their own representations of science, allowing them to work with content as active producers of science communication, rather than as passive consumers. For example, a successful project having students make science comics [de Hosson et al., 2018] allowed for students to explore the content and storytelling aspects of science together, but mostly focus on students' writing skills. Since 2015, social media platforms YouTube, Shapchat, and Instagram have surpassed Facebook to become the most popular with adolescents, and all centre on the production of photo and video stories [Anderson and Jiang, 2018]. To encourage and support all students in their learning, we must take advantage of the many forms of literacies that current students communicate through [Ainsworth, Prain and Tytler, 2011; Thibaut and Curwood, 2018], and occupy the space of digital, video, and audio texts with science storytelling.

Storytelling is an ancient and powerful practice [Smith et al., 2017] that has adapted its form to the spaces humans have occupied over millennia. From campfires and caves to printing presses and lecture theatres, stories now find themselves diversified throughout the digital realm. Mobile devices allow learners to access and create stories constantly in this digital space, and communicate through multiple literacies simultaneously [MacCallum et al., 2017]. Mobile devices are ubiquitous with adolescents, with $91 \%$ of participating students in the Programme for International Student Assessment (PISA) 2015 having access to a smartphone and $53 \%$ having access to a tablet device (the fastest growing device, having risen 30\% points between PISA 2012 and 2015) [OECD, 2017]. The advantages these devices can offer underpin the need to develop teaching practices which effectively implement their use [Crompton et al., 2016]. Moving towards the active production of films on mobile devices offers the opportunity to utilise readily available 
technology, learn scientific content, and develop skills in communication. [Rifkin et al., 2010]. Though evidence exists supporting the use of science communication activities and mobile-filmmaking as ways to engage students, it is mainly based in tertiary courses [Clarkson et al., 2018; Speed, Lucarelli and Macaulay, 2018], where it is too late for students who opted-out from science years earlier.

\section{Research questions}

With the need of strategies to engage school students with science during crucial adolescent decision-making years, we investigate the opportunity to connect school students to science through the process of mobile-filmmaking. In this exploratory project where students acted as storytellers in the production of their own science film, we asked:

I. Does storytelling through mobile-filmmaking improve student engagement with science in the classroom?

II. What are the benefits and challenges of telling science stories with mobile-filmmaking in the classroom for teachers and students?

In this report, we first establish the design, collection, and analysis of data related to student engagement in conducting a mobile-filmmaking project in schools. Next, we explore and discuss the themes that emerged from our analysis relating to student and teacher experiences related to their engagement with the Science Video Project (SVP). Finally, we suggest future directions for research into engaging adolescents as storytellers, as well as implications for practitioners and researchers.

\section{Defining engagement}

Science engagement can be investigated in a wide spectrum of contexts from the individual up to the community or cultural level [Sinatra, Heddy and Lombardi, 2015]. While using eye-tracking software to measure cognitive engagement of students during a science lesson [Miller, 2015] and investigating post-normal science and its effects on global and future issues [Funtowicz and Ravetz, 1993] may lie at opposite ends of this spectrum, both are useful for investigating the ways we interact with science in our lives. In this study we focus on the person-in-context area of the spectrum [Sinatra, Heddy and Lombardi, 2015] as we measure student engagement in the context of a particular science learning activity. This type of school engagement is a predictor of positive outcomes for pursuing and excelling in science [Tytler and Osborne, 2012].

While student engagement in science at school is largely agreed upon to be a multidimensional construct, and even a metaconstruct, new dimensions are still being developed [Fredricks, Blumenfeld and Paris, 2004]. There is evidence to support three central dimensions for the way that students engage with their science classroom experience (including engagement with their learning, class, teacher or classmates) which we focused on in this study; behavioural (what students do), emotional (how students feel), and cognitive (how students think) [Sinatra, Heddy and Lombardi, 2015]. Social [Finn and Zimmer, 2012] and agentic 
dimensions [Reeve and Tseng, 2011] have also been suggested, though these still require further validation and definition.

Defining our investigation of engagement with science in this manner has implications for analysis and interpretation of results. Primarily, by focusing on engagement with a particular learning activity in the classroom, student and teacher comments are taken to correspond to the science class rather than to Science as a culture, practice, or career. Additionally, focusing on in-class engagement of students in a particular learning task does not take into consideration influences outside the classroom such as familial, economic, or cultural factors that have previously been shown to affect science interest and aspirations of adolescent students [Archer et al., 2012].

The SVP was comprised of four 1-hour lessons during regular class time, including activities in researching, storyboarding, filming, and editing to produce a $<4$-minute video. Worksheets that accompanied these activities can be found as supplementary material. After being given project materials and an introduction to the project, teachers were encouraged to adapt the project to fit their curriculum needs and timetable. These teachers were not technology specialists, and carried out the project using their own class time with their regular class of students. Two teachers had their classes make videos on any science topic (could be outside of curriculum learning), while the other two classes had topic guidelines put in place to reflect their current curriculum learning areas. Class sizes ranged from 25-30 students who worked together in teams of 3-4 to produce their science video.

\section{Participants}

The participants were comprised of the teachers and students in four adolescent classes in an urban centre in the New Zealand. Three teachers with at least five years teaching experience participated in the study. Two classes were chosen at Year 8 (12-13yo) and two at Year 10 (14-15yo). These year levels were of interest because they represent two important transitions for students during middle-years schooling. At Year 8, students are on the cusp of transitioning to high school where they will have a dedicated science class and teacher for the first time. After Year 10, high school students transition to senior schooling, when they can opt-out of science subjects if they wish. Classes were selected purposively to capture the student and school diversity in New Zealand, such as special character (single-sex or religious affiliation), school type (high school or intermediate), and student diversity (ethnicity and gender) as shown in Table 1.

\section{Ethical approval}

Written consent was provided by all teachers to be involved in the study. As the student participants were minors, consent was provided by their guardians. Those who participated in interviews were required to provide additional consent for their responses to be audio recorded. For all participants, consent included 
Table 1. School Characteristics. Please note that all school names are pseudonyms.

\begin{tabular}{|c|c|c|c|}
\hline Case Site & Age & Distinctive Factor(s) & 'Science' Taught By \\
\hline Moana College & $14-15$ & $\begin{array}{c}\text { Single-sex } \\
\text { (female) }\end{array}$ & Science Teacher - A1 \\
\hline St. Duke Academy (10) & $14-15$ & $\begin{array}{c}\text { Religious } \\
\text { special character }\end{array}$ & Science Teacher - BC2 \\
\hline St. Duke Academy (8) & $12-13$ & $\begin{array}{c}\text { Combined intermediate } \\
\text { and high school }\end{array}$ & Primary Teacher - D3 \\
\hline Dragon Valley Middle School & $12-13$ & $\begin{array}{c}\text { Highest \% of non-European } \\
\text { students in study area }\end{array}$ & \\
\hline
\end{tabular}

permission to video record and disseminate anonymised results. Before beginning recruitment, this study was approved by the Human Ethics Committee of the authors' university.

\section{Materials}

Classes were provided with a set of 16 iPads (iPad Air 2), capable of video and photo capture and preloaded with the editing software iMovie. While utilisation of student or school owned devices is an ultimate goal, we chose to standardise the devices used during the project for three research-related reasons. First, standard devices and software allowed for comparison of video production process between students and classes. Second, supplying the iPads controlled for varying device access and type. Third, this allowed for secure storage of potentially identifiable video, audio and images of students. All participating schools had Bring Your Own Device policies. Students were allowed to use their own additional devices for information researching purposes only. All filming and editing was conducted on the iPads for the reasons stated above. Teachers were also provided with a project guide and accompanying student activity packet that directed students through the process of making a short film as found as supplementary material.

\section{Data collection}

Measurement of the metaconstruct 'engagement' is particularly challenging. Sinatra, Heddy and Lombardi [2015] suggest that for an investigation interested in exploring student engagement in the context of a specific learning activity, appropriate methods include experience sampling, observations of interactions, and triangulated self-report measures. Experience sampling [Hektner, Schmidt and Csikszentmihalyi, 2007] was not a viable option for this study as resources were not available to provide students with 1-to-1 research devices, activity length did not allow for adequate time for multiple samplings, and drawing students' attention away during such a short time span could have artificially affected their overall engagement and success with the task.

We focused on observing classroom interactions and triangulating engagement through self-report measures to improve validity [Bazeley, 2013]. We implemented a multiple case study design [Cohen, Manion and Morrison, 2013] consisting of 
semi-structured interviews [Bogdan and Biklen, 1997] with teachers, group interviews with students, student questionnaires, and researcher observations.

Conner et al. [2009] suggest that for short activities like the SVP, one-off self-reports following the event are least burdensome to participants. For this reason, all students were given the opportunity to provide feedback on the project in a post questionnaire. These were collected using the Qualtrics app preloaded onto the iPads students used for the project.

Interviews were conducted within one week before and after the SVP. These were held during typical break times so as to minimise disturbance to participants' schedules. Teachers selected 4-6 students for the group interviews, which they felt represented the diversity of their classroom, but who would feel comfortable talking with each other and the researcher. Eder and Fingerson [2001] suggest that the most important factor in designing interviews with children is to create a natural context. As such, interviews were held with classmates, in a typical break spot or classroom, and students were encouraged to speak openly.

Pre-interview questions aimed to describe typical student engagement in the class and expectations of the project. The post-interview similarly aimed to have describe student's engagement as a result of the project as well as benefits and challenges the experienced. All interview data were audio recorded, and subsequently transcribed by the primary author using HyperTranscribe [Researchware Inc., 2013]. Initial transcription was followed by two rounds of reviewing to ensure that the transcripts accurately reflected the recorded sessions.

\section{Data Analysis}

A mix of deductive and inductive coding was applied to the data to address the main research questions [Saldaña, 2015]. To address the first research question we employed a pre-established list of operationalised engagement indicators to code comments from interviews and questionnaires. Fredricks, Wang et al. [2016, pp. 9-10] developed a list of behavioural, emotional, and cognitive indicators related to students' engagement or disengagement in science class. This list operationalises what students and teachers identify as signs of their engagement with science, opposed to a researcher-devised definition of the construct. We searched student and teacher comments for signs of the engagement indicators, which were used as codes for interview and questionnaire responses. There were six categories, which were broken down into $n$ specific indicators; emotional engagement $(n=15)$, behavioural engagement $(n=19)$, cognitive engagement $(n=15)$, emotional disengagement $(n=15)$, behavioural disengagement $(n=19)$, and cognitive disengagement $(n=6)$. For a complete list of indicators see Table 1 (pp. 9-10) in Fredricks, Wang et al. [2016]. Researcher observations were used as a secondary source to provide context to participant responses. To ensure reliability of the coding procedure, one teacher and one student group interview were initially coded, and then recoded two weeks later until the researcher was able to apply the indicator codes consistently as in Mackey and Gass [2005].

To identify the benefits and challenges of the project for participants, inductive coding of transcripts was implemented [Saldaña, 2015]. This proceeded in three 
rounds of generating and rechecking codes so that they were comparable across cases. The initial round proceeded with in vivo coding [Miles and Huberman, 1994], creating codes based on the words of participants. Initially there were 23 codes describing benefits, and 21 codes related to challenges. Over a further two cycles, codes were compared and condensed into 20 categories, representing three major themes related to storytelling and mobile-filmmaking.

\section{Results}

Here we present the results of the SVP and the themes related to our two research questions. The science mobile-filmmaking project was found to positively affect student engagement with science and develop skills across the curriculum. These claims are supported by six themes which emerged from our analysis which can be summarised as:

I. Student disengagement is mainly due to transmissive teaching styles.

II. Mobile-filmmaking engages students through the exciting and collaborative process of storytelling.

III. Students learn science content through the repetitive nature of the storytelling process while making their own short films.

IV. Mobile-filmmaking allows development of soft skills in the science classroom.

V. Cross-curricular goals can be achieved through mobile-filmmaking by integrating - at a minimum — science, literacy, and digital technology learning.

VI. Fast-paced storytelling projects may encourage engagement, but adjustments may allow for further learning goals to be accomplished.

In this section, we present evidence to support these themes then examine them in relation to the wider literature leading into a discussion of future opportunities for practitioners and researchers to investigate mobile-filmmaking.

\section{Engagement}

In Figures 1 and 2 we present a visual summary of the percentage of engagement indicators during discussions with students and teachers. Figures 1 and 2 show the proportion of interview comments related to behavioural, emotional, and cognitive engagement or disengagement. It is immediately evident that there is a large shift in student and teacher comments between discussing their typical science class and their experience after the SVP. In the following two sections, we explore the sources of these shifts.

Theme I: typical science classes struggle to engage. Before beginning the project, interview comments related to engagement $(n=110)$ showed that across four classes the average level of disengagement was 52\% (Figure 1). The two classes at St. Duke's showed slightly higher than average disengagement (64\% and 75\%) and the classes at Dragon Valley and Moana College showed slightly less than average 


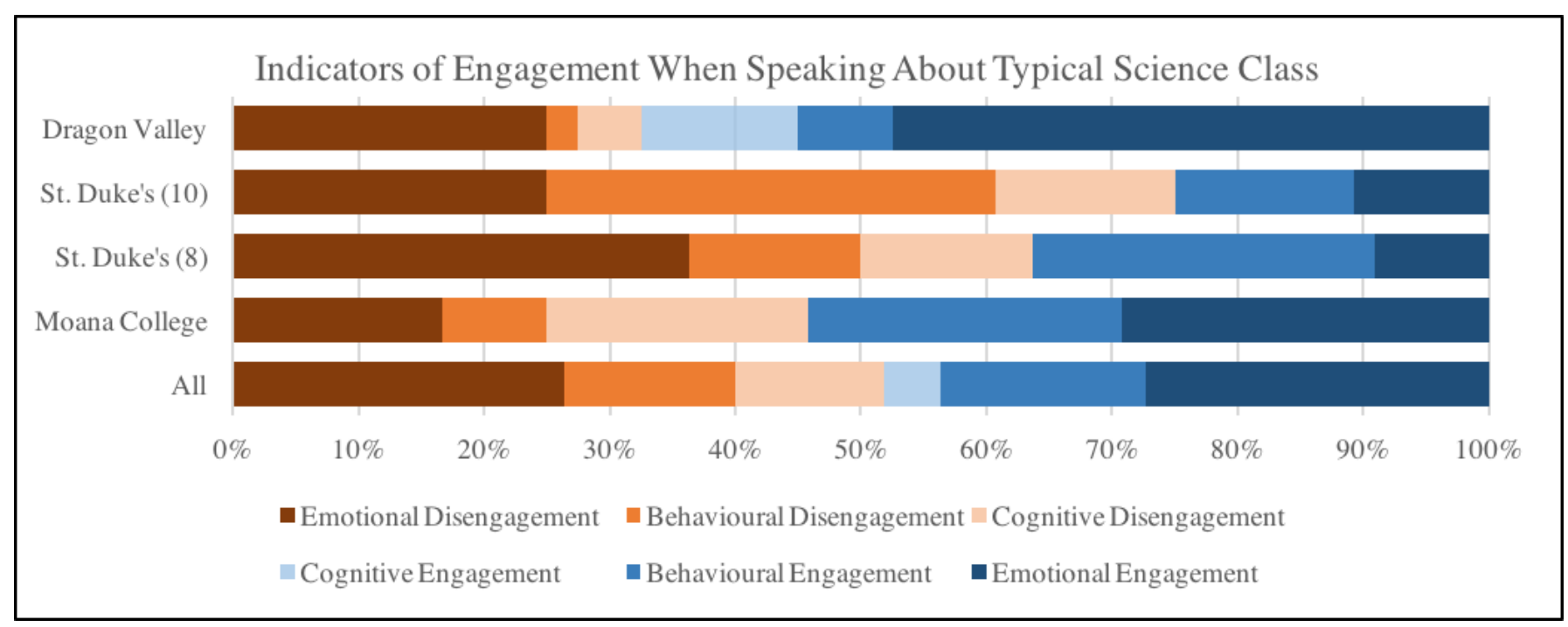

Figure 1. Typical Science Class Engagement. Here we represent the engagement indicators that were mentioned during discussions with student and teachers about their science class. Overall there were $n=110$ comments related to engagement in typical science class.

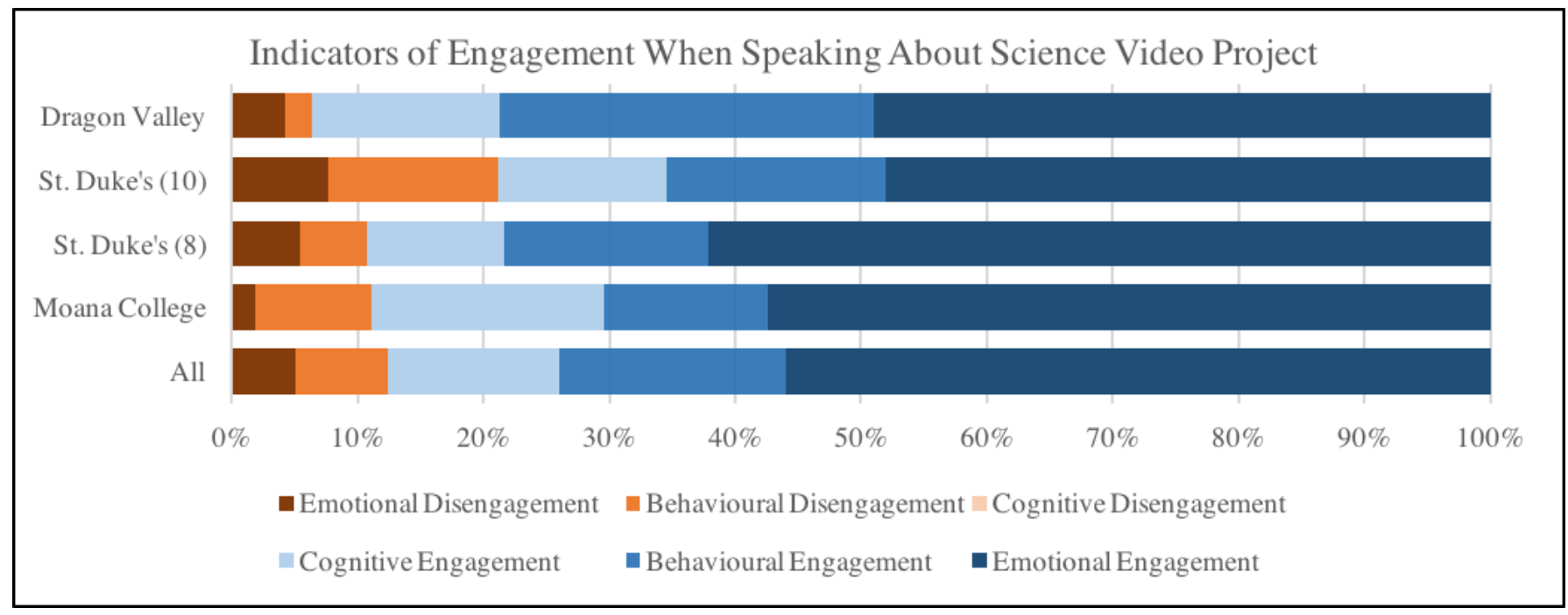

Figure 2. SVP Engagement. Here we represent the engagement indicators that were mentioned during discussions with student and teachers about their science class. Overall there were $n=177$ comments related to engagement with the SVP.

disengagement ( $33 \%$ and $46 \%$ respectively). This substantial difference is due to a higher prevalence of transmissive teaching styles in the two classes at St. Duke's.

The majority of disengagement indicators in discussions before the project were related to expressions of boredom with transmissive lessons, where Science instruction came mainly in the form of listening to the teacher and writing notes. The prevalence of these comments would almost suggest that writing notes is a 'trigger' [Renninger and Bachrach, 2015] for some students' disengagement, as one student commented: 
Student 2-2a: Just writing for the whole class, that's basically what we do every time except for a couple lucky times where we actually get to do something fun.

This student's disdain for science is not based on the content, but in the way they are being taught. Students who experience transmissive teaching styles are likely to experience poor content learning, views of science as a static collection of knowledge, and little opportunity for discussion and personalisation of learning [Lyons, 2006]. Students suggested that they were engaged in 'something fun' when doing experiments or conducting Science Fair projects. However, disappointment was also expressed with the low frequency with which these enjoyable hands-on activities were conducted. Teachers seemed to be aware of this trend, confirming that:

Teacher 2: They're the kind of class that prefers to be more active, they'll tell you anything, but they don't like to write stuff down.

Despite this teacher's awareness of students' preference for lively teaching activities, the status quo remains. This view that science classes are boring is an unfortunate international phenomenon [Lyons, 2006], as well as a leading cause for students to opt-out of science courses [Cleaves, 2005]. Here we see that before beginning the project, students were lukewarm in both year levels about their engagement with science. The prevalence of transmissive styles of teaching raises significant concern for their engagement and interest in science at a critical time in their academic development.

Theme II: mobile-filmmaking improves engagement. After conducting the project in class, interview comments related to engagement $(n=177)$ showed a large increase in engagement indicators (Figure 2) related to mobile-filmmaking. In the St. Duke's (10) class, however, comments about disengagement (21\%) were higher than any other class. This was mainly due to higher levels of comments regarding behavioural disengagement, mainly related to students identifying their peers as being off-task or goofing around. We further investigated whether this was due to some aspect of the project. This sort of behavioural disengagement was described as being typical for this class and would have occurred with any other activity.

Teacher 2: I don't know if it would have been any better with any other type of group or resource... I think probably they got more out of it than they would have out of a paper, so on balance, I think the outcome was probably better.

Despite these comments, an overall increase in engagement levels was found during the project. Students commenting that they were very pleased to be doing something they felt personally involved with replaced disengaging comments about transmissive teaching styles that had dominated discussions before the project. In producing their own science stories, students had the opportunity to contribute their own thoughts and understandings of content to a wider discussion. When comparing the SVP to other research projects, one student commented:

Student 2-3: ... it wasn't just like a normal research project where you get something, you put it on a Google Doc or Slide. You got to do your own thing and customise it to you, whereas with writing it's just your skill. 
The storytelling process while producing films required students to gather, interpret, and reproduce information - at every stage infusing their film with touches of their own personalities, words and depictions, or 'customising it' to themselves. The process of filming, and the film itself, became a discussion between students and others. A lack of discussion and creativity in science class activities are two reasons for student disengagement [Osborne and Collins, 2001; Lyons, 2006]. It is our suggestion that this opportunity enhances the newly suggested agentic dimension of student engagement where students participate in instruction. Students who are experiencing agency in their learning purposefully contribute input and suggestions into the learning process [Reeve, 2012; Sinatra, Heddy and Lombardi, 2015]. By having control over the storytelling process, students could contribute their ideas, creativity, and learning actively in a way that was not possible with passive note taking.

This overall increase in engagement indicators was largely due to an increase in the dimension of students' emotional engagement (Figure 2). Almost all participants commented that the project was fun, enjoyable, and exciting, similar to the way they felt about doing experiments and other hands-on activities. Enjoyment acts as a stimulus for interest in science, and can also be associated with effort [Pekrun, 2006] and problem solving [Csikszentmihalyi and Csikszentmihalyi, 1975]. Finally, there was a trend for students to identify that they liked the project because they got to work with others throughout the project. As one student and teacher described:

Student 5-2b: I guess when you're just writing it down you just write it down. But when you do it as a video, you're kind of teaching people... and when you teach them you have to understand it better yourself.

Teacher 3: And we ended up sharing the work at assembly, and they were really proud to share their [videos].

Students taught themselves and peers through storytelling, and felt pride in sharing their stories with others which enhanced engagement. This social trend may well be related to a social dimension of student engagement [Finn and Zimmer, 2012]. While producing their film, students were in a social-bubble, continuously assessing whether their descriptions and depictions would be understood by their audience.

Looking at these results as a whole, we can see that increased engagement was a result of students actively contributing and experiencing more agency in the filmmaking process than they did with typical lessons. The significant increases in emotional engagement in particular were a result of students' having the opportunity to work on a collaborative project that was exciting and enjoyable. Both of these positive impacts on student engagement are a result of the active process of creating stories with and for others.

\section{Benefits and challenges}

Additional benefits and challenges associated with the project emerged that were not represented by the indicators used to classify engagement. We discuss the three most cited benefits relating to storytelling, project management, and cross-curricular goals as well as the challenge of time that many participants experienced. 
Theme III: learning through storytelling. Closely tied to the increases in emotional engagement were two important qualities of the storytelling experience; filmmaking and creative expression. Students described that part of what made the project more fun and exciting was getting to develop their filming and editing skills and getting to express their learning, creativity, and humour. Through this storytelling experience, students felt that they could enjoy the content they were learning throughout the process of researching and producing their videos. We argue that it was the process of filmmaking that allowed students to revise and learn material in a new way that aided their understanding and enjoyment of learning. When asked how the project affected their learning, one intermediate student described:

Student 6-3: ... when you're doing your subject on the video, you get to go over it lots of times which helps me remember it. When you're writing it down you may read it once or twice and then that's it.

Having the chance to work through content many times throughout the filmmaking process allowed students to build their understanding of their scientific topics as they built their stories. This was a benefit that was also recognised by teachers:

Teacher 2: Sometimes... when we ask them to do a project, they copy and paste it. And so, I think [the SVP] forces them to actually synthesise the information and put it in their own words simply.

While filmmaking, students enthusiastically conducted multiple rounds of planning, rehearsing, and presenting material to 'put it in their own words'. It has been suggested this would be similar to the benefits of repeated readings of written text, which encourage fluency with the material [Young and Rasinski, 2013]. Repetition and multiple opportunities to digest information relates to the dynamic process of storytelling, which is a better reflection of the scientific method than the "static, linear, non-participatory' view that transmissive styles of teaching and textbooks would suggest [Martin and Miller, 1988, p. 60]. In addition to the benefits of developing skills in filmmaking and creativity, students are also engaged in a more authentic form of learning science content through storytelling.

Theme IV: developing soft skills and self-efficacy. Teachers expressed different initial concerns that seem to be based on the difference in how secondary and primary teachers are typically trained. The two high-school teachers (Science content-area) were mainly concerned with not having the technology or storytelling skills to implement the project. The intermediate teacher from Dragon Valley (generalist teacher) making videos were somewhat common, and that they were more concerned with not having enough science training. As the intermediate teacher summarised:

Teacher 3: We probably don't have the science knowledge that we need, but then we have the literacy stuff. And science classes frequently, in my experience of them, high school styles didn't have much fun in terms of literacy stuff... all the note taking and gathering through a textbook and that kind of stuff. 
Reflecting on the project, however, teachers found that they did not encounter significant technology, storytelling, or science concept issues. Where issues did arise in these areas, all three teachers welcomed the opportunity to demonstrate problem solving skills with their students. When describing how they did assist students, teachers commented:

Teacher 1: I thought I was going to get a lot of science questions, but it was more about project management side of things... So it wasn't really scientific help, it was more... trying to get it done help.

Teacher 2: Yeah, I don't think it was a technology issue. It was probably not even with projects... it's with managing themselves.

Teacher 3: I think it's a better approach to teach project management.

These teachers seem to have spent most of their time during SVP lessons assisting students with general soft-skill challenges [Heckman and Kautz, 2012] managing team member interactions, time, and resources. This unexpected benefit of the SVP highlights the opportunity for using mobile-filmmaking as a tool to develop student' self-efficacy skills - defined by Bandura, Freeman and Lightsey [1999] as the "beliefs in one's capabilities to organise and execute the courses of action required to manage prospective situations"[p. 3]. Through modelling and practising these skills, students stand to increase their self-efficacy and confidence with the project. Increased confidence then furthers their likelihood to engage and enjoy the activities, creating a self-fulfilling cycle [Pajares, 1996]. In this way, a positive experience with science mobile-filmmaking as we have found in this study allows development of students' soft-skills and self-efficacy, and can in turn further inspire their interests in science and its communication.

Theme V: fulfilling cross-curricular goals. Teachers also found the project beneficially integrated aspects of literacy and communication into Science lessons. The New Zealand Curriculum [Ministry of Education, 2007] was designed to encourage cross-curricular lessons, though many teachers find these difficult to implement with current school structures. In addition to content strands, the Science Learning Area also has a Nature of Science strand which is meant to be integrated with the other content areas [Ministry of Education, 2007] and highlights the importance of the way science is carried out and communicated.

For the intermediate teacher (11-13 years old) who felt more confident teaching literacy skills rather than science content, the project gave a new way to comfortably expand the science areas of their lessons:

Teacher 3: You do such integrated curriculums... Normally when I'm getting the kids to make a video, I'm thinking Literacy, and not thinking Science, so that [is] a good challenge, to go in where this is thinking about Science.

Whereas for the high school teacher (12-16 years old) who mostly focused on teaching science content in their classes, the project allowed for aspects of the way science is communicated to be enhanced in their lessons: 
Teacher 2: [The SVP] encourages assessment in an oral form, because in science we need to be able to communicate orally as well.

Additionally, the SVP presents an ideal method to incorporate skill-building activities in digital communication as well. In New Zealand, a newly released Digital Technologies curriculum will be required to be taught in schools by 2020 [Ministry of Education, 2017]. In addition to Science and Literacy, the mobile-filmmaking project provides an opportunity to accomplish further cross-curricular goals in designing and understanding digital media outcomes.

Theme VI: finding the right amount of time. In discussions and observations, the most often mentioned challenge was not having enough time to finish the videos. The SVP was planned as four 1-hour lessons so teacher could easily integrate the project into their existing timetables. This was less time compared to other student video-making projects, which could last for weeks [Young and Rasinski, 2013] or even months [Hubbard, 2012].

Two trends emerged in the ways students struggled with timing in the project. First, some struggled to 'get going' with planning (so ran out of time for filming/editing). Second, other groups spent too much time filming and ran out of time for editing. It is worth noting, however, that of the twenty-nine videos that were collected during the project, only six remained incomplete (videos recorded, but not edited together). When asked about the pace of the project, one student commented:

Student 6: I did feel a bit more engaged because we don't have a big time-frame that we can do it in. We had a short, sweet, time and so you have to kind of focus.

While students may have wanted more time, the fast-paced production encouraged efficient working. Teachers also discussed timing challenges, with Teacher 3 describing it as a 'tight rope' because giving more time for the project could make it 'lose its impetus'. One teacher was given the opportunity to conduct the project twice with different classes and described that:

Teacher 2: It went okay the first time but, it was easier the second time. And I don't think it was the students necessarily, probably was just experience with the project... And when you've done it once you sort of know the timeline where you need to push them a wee bit.

This teacher's comments indicate that if adopted regularly by teachers, repetition of the project would allow for the teacher and students to become more comfortable and confident in completing videos as part of a regularly allotted class activity. Teachers also showed excitement for the possibilities of extending and adapting the project to fit their classroom goals further. The project could be expanded to include a scientific investigation or experiment, lessons added to coach students in group work, explicit literacy/communication instruction, links to other classes such as Digital Technologies or Literacy, use as an exam revision tool, or conducted as a form of assessment. As the project expands to include these interesting opportunities, however, it could lose its simplicity of implementation, and thus be less likely to be realistically utilised by educators. 
The exploratory nature of this research project put limits on the investigation. A small number of case sites and variables were able to be investigated mostly due to time, resources, and teacher curricular requirements. Omitted from our study was the effect of mobile-filmmaking on content learning because this would have required a standardised video topic across classrooms, which would have been nearly impossible considering differences in curricula between year levels and topics taught at a given time between classrooms. Now that we have found strong signs of improved engagement through the process of telling science stories through mobile-filmmaking, a future replication of this study incorporating effects on learning is strongly encouraged as learning improvements would be key to the activity being conducted regularly in classrooms.

Investigating variables such as ability for assessment and likelihood of activity adoption by teachers would further reveal the sustainability of such projects in the typical classroom. These would benefit from a long-term study, allowing students and teachers to experience the project multiple times as a regular part of their classroom activities. With this study as an exploratory grounding, comparing the experience of science mobile-filmmaking with the production other formats of science storytelling not requiring expensive technology (e.g. live shows, games, writing, or comics) would further reveal the potential to engage adolescents as storytellers.

\section{Implications for research and practice}

The science mobile-filmmaking project was designed as a solution in the 'third space' between science education and communication for declining student engagement. As such, there are unique implications for both formal educators and science communicators, and the researchers in both fields.

\section{Science education.}

1. Science mobile-filmmaking increases students' engagement in science class, especially for students turned-off to science due to frequent reading and writing activities.

2. Students develop science, literacy, and technology-related skills as well as those in problem solving, group work, and project management which could achieve current assessment standards.

3. Producing a $<4$-minute video on a mobile device is possible, but challenging, for students in four one-hour lessons. Added lessons or time should remain germane to educator's learning goals and not just give 'more time' for its own sake.

4. Successful with students 12-15 years of age, in high schools and intermediate schools, with a wide range of science topics, and taught by generalist and science-specialist teachers. 


\section{Science communication.}

1. Empowering adolescents as producers rather than consumers of science stories via mobile filmmaking is a powerful way to engage them with science.

2. Use of Fredricks, Wang et al. [2016] indicators successfully captured participants' engagement with science. Further development of indicators and validation of their accurate measure of engagement with science could be fortuitous research pathways.

3. Exploring joint solutions between science communication and education researchers has produced a successful project, and like partnerships are encouraged to address issues facing both fields.

\section{Conclusion}

The need for strategies to spark engagement in science for students at school is necessary to develop informed and engaged future citizens. Engagement is a key focus of science communication research and transferring methods to science education can be of benefit to both disciplines. In this study, we set out to explore the engagement value of school students communicating science stories through mobile-filmmaking. In four 1-hour sessions during typical class time, students produced their own science films on a mobile device with the support of their regular teacher.

The experience of combining storytelling with science through mobile-filmmaking found students more engaged than in their typical science class. Where students were feeling disconnected and bored, mobile-filmmaking gave students the opportunity to bring their creativity, thoughts, and skills to the storytelling process and to enjoy learning science content with their peers. Science does not exist in vacuum as a static practice or body of knowledge, though it is often taught in precisely this manner in schools. Both science-specialist and generalist teachers found that science mobile-filmmaking gave the opportunity to enrich regular science lessons with literacy, digital technologies, and personal development skill building opportunities. Engaging students as storytellers through mobile-filmmaking has been found here to be a powerful engagement method, and warrants further investigation, especially into its effects on content learning.

Acknowledgments We thank the educators and students who made this research possible, and the University of Otago for the doctoral scholarship which supported the first author in conducting this project.

\section{References}

Ainsworth, S., Prain, V. and Tytler, R. (2011). 'Drawing to learn in science'. Science 333 (6046), pp. 1096-1097. https://doi.org/10.1126/science. 1204153.

Anderson, M. and Jiang, J. (2018). Teens, social media \& technology 2018. Washington, DC, U.S.A.: Pew Internet \& American Life Project.

Archer, L., DeWitt, J., Osborne, J., Dillon, J., Willis, B. and Wong, B. (2012). 'Science aspirations, capital and family habitus: how families shape children's engagement and identification with science'. American Educational Research Journal 49 (5), pp. 881-908. https: //doi .org/10 .3102/0002831211433290. 
Bandura, A., Freeman, W. H. and Lightsey, R. (1999). 'Self-efficacy: the exercise of control'. Journal of Cognitive Psychotherapy 13 (2), pp. 158-166.

https://doi.org/10.1891/0889-8391.13.2.158.

Baram-Tsabari, A. and Osborne, J. (2015). 'Bridging science education and science communication research'. Journal of Research in Science Teaching 52 (2), pp. 135-144. https://doi.org/10.1002/tea.21202.

Bazeley, P. (2013). Qualitative data analysis: practical strategies. Sage.

Bogdan, R. and Biklen, S. K. (1997). Qualitative research for education. Boston, MA, U.S.A.: Allyn and Bacon, Inc.

Clarkson, M. D., Rohde, J., Houghton, J. and Chen, W. (2018). 'Speaking about science: a student-led training program improves graduate students' skills in public communication'. JCOM 17 (02), A05. https://doi.org/10.22323/2.17020205.

Cleaves, A. (2005). 'The formation of science choices in secondary school'. International Journal of Science Education 27 (4), pp. 471-486. https://doi.org/10.1080/0950069042000323746.

Cohen, L., Manion, L. and Morrison, K. (2013). Research methods in education. Hoboken, NJ, U.S.A.: Taylor and Francis.

Conner, T. S., Tennen, H., Fleeson, W. and Barrett, L. F. (2009). 'Experience sampling methods: a modern idiographic approach to personality research'. Social and Personality Psychology Compass 3 (3), pp. 292-313. https://doi.org/10.1111/j.1751-9004.2009.00170.x.

Crompton, H., Burke, D., Gregory, K. H. and Gräbe, C. (2016). 'The use of mobile learning in science: a systematic review'. Journal of Science Education and Technology 25 (2), pp. 149-160. https: //doi .org/10. 1007/s10956-015-9597-x.

Csikszentmihalyi, M. and Csikszentmihalyi, I. (1975). Beyond boredom and anxiety. San Francisco, CA, U.S.A.: Jossey-Bass.

de Hosson, C., Bordenave, L., Daures, P.-L., Décamp, N., Hache, C., Horoks, J., Guediri, N. and Matalliotaki-Fouchaux, E. (2018). 'Communicating science through the Comics \& Science Workshops: the Sarabandes research project'. JCOM 17 (02), A03. https://doi .org/10.22323/2.17020203.

de Vries, M. J. and van der Sanden, M. C. A. (2016). 'Science and technology education and communication: seeking synergy'. In: Rotterdam, The Netherlands: SensePublishers. https://doi .org/10 . 1007/978-94-6300-738-2.

Driver, R., Leach, J., Millar, P. and Scott, P. (1996). Young people's images of science. Buckingham, England: Open University press.

Eder, D. and Fingerson, L. (2001). 'Interviewing children and adolescents'. In: Handbook of interview research. Ed. by J. F. Gubrium and J. A. Holstein. SAGE Publications, Inc., pp. 181-201. https : //doi .org/10.4135/9781412973588.n13.

Finn, J. D. and Zimmer, K. S. (2012). 'Student engagement: what is it? Why does it matter?' In: Handbook of research on student engagement. Boston, MA, U.S.A.: Springer, pp. 97-131. https://doi .org/10.1007/978-1-4614-2018-7_5.

Fredricks, J. A., Blumenfeld, P. C. and Paris, A. H. (2004). 'School Engagement: Potential of the Concept, State of the Evidence'. Review of Educational Research 74 (1), pp. 59-109. https://doi.org/10.3102/00346543074001059.

Fredricks, J. A., Wang, M.-T., Linn, J. S., Hofkens, T. L., Sung, H., Parr, A. and Allerton, J. (2016). 'Using qualitative methods to develop a survey measure of math and science engagement'. Learning and Instruction 43, pp. 5-15. https://doi.org/10.1016/j.learninstruc.2016.01.009.

Funtowicz, S. O. and Ravetz, J. R. (1993). 'Science for the post-normal age'. Futures 25 (7), pp. 739-755. https://doi .org/10.1016/0016-3287 (93)90022-L. 
Heckman, J. J. and Kautz, T. (2012). 'Hard evidence on soft skills'. Labour Economics 19 (4), pp. 451-464. https://doi.org/10.1016/j. labeco.2012.05.014.

Hektner, J., Schmidt, J. and Csikszentmihalyi, M. (2007). Experience sampling method: measuring the quality of everyday life. SAGE Publications, Inc. https://doi.org/10.4135/9781412984201.

Hipkins, R. (2012). Building a science curriculum with an effective nature of science component. New Zealand: Ministry of Education.

URL: https://www.nzcer.org.nz/research/publications/building-science -curriculum-effective-nature-science-component-0.

Hubbard, G. T. (2012). 'Discovering constructivism: how a project-oriented activity-based media production course effectively employed constructivist teaching principles'. Journal of Media Literacy Education 4 (2), p. 6. URL: https://digitalcommons .uri.edu/jmle/vol4/iss2/6.

Lederman, N. G. (2007). 'Nature of science: past, present and future'. In: Handbook of research on science education. Ed. by S. K. Abell and N. G. Lederman. Mahwah, NJ, U.S.A.: Lawrence Erlbaum Associates, pp. 831-879.

Lindahl, B. (2007). 'A longitudinal study of students attitudes toward science and choice of career'. Paper presented at the $80^{\text {th }}$ NARST International Conference, New Orleans, LA, U.S.A.

Lyons, T. (2006). 'Different countries, same science classes: students' experiences of school science in their own words'. International Journal of Science Education 28 (6), pp. 591-613. https://doi.org/10.1080/09500690500339621.

MacCallum, K., Day, S., Skelton, D. and Verhaart, M. (2017). 'Mobile affordances and learning theories in supporting and enhancing learning'. International Journal of Mobile and Blended Learning 9 (2), pp. 61-73. https://doi.org/10.4018/ijmbl.2017040104.

Mackey, A. and Gass, S. M. (2005). Second language research: methodology and design. Routledge.

Maltese, A. V. and Tai, R. H. (2010). 'Eyeballs in the fridge: sources of early interest in science'. International Journal of Science Education 32 (5), pp. 669-685.

Martin, K. and Miller, E. (1988). 'Storytelling and science'. Language Arts 65 (3), pp. 255-259. URL: https://www. jstor . org/stable/41411379.

Miles, M. B. and Huberman, A. M. (1994). Qualitative Data Analysis: An Expanded Sourcebook. 2nd ed. London, Thousand Oaks, New Delhi: SAGE Publications.

Miller, B. W. (2015). 'Using reading times and eye-movements to measure cognitive engagement'. Educational Psychologist 50 (1), pp. 31-42. https://doi.org/10.1080/00461520.2015.1004068.

Ministry of Education (2007). The New Zealand curriculum. New Zealand.

- (2017). How we've stregthened digital technologies $\mathcal{E}$ Hangarau Matihiko content in the curriculum. New Zealand.

OECD (2017). PISA 2015 results (volume III). Paris, France: OECD Publishing. URL: https://www.oecd.org/education/pisa-2015-results-volume-iii-978 9264273856-en.htm.

Osborne, J. and Collins, S. (2001). 'Pupils' views of the role and value of the science curriculum: a focus-group study'. International Journal of Science Education 23 (5), pp. 441-467. https://doi.org/10.1080/09500690010006518.

Osborne, J., Simon, S. and Collins, S. (2003). 'Attitudes towards science: a review of the literature and its implications'. International Journal of Science Education 25 (9), pp. 1049-1079. https://doi.org/10.1080/0950069032000032199.

Pajares, F. (1996). 'Self-efficacy beliefs in academic settings'. Review of Educational Research 66 (4), pp. 543-578. https://doi.org/10.3102/00346543066004543. 
Pekrun, R. (2006). 'The control-value theory of achievement emotions: assumptions, corollaries and implications for educational research and practice'. Educational Psychology Review 18 (4), pp. 315-341. https://doi.org/10.1007/s10648-006-9029-9.

Potvin, P. and Hasni, A. (2014). 'Interest, motivation and attitude towards science and technology at K-12 levels: a systematic review of 12 years of educational research'. Studies in Science Education 50 (1), pp. 85-129. https://doi.org/10.1080/03057267.2014.881626.

Reeve, J. (2012). 'A self-determination theory perspective on student engagement'. In: Handbook of research on student engagement. Boston, MA, U.S.A.: Springer, pp. 149-172. https://doi .org/10.1007/978-1-4614-2018-7_7.

Reeve, J. and Tseng, C.-M. (2011). 'Agency as a fourth aspect of students' engagement during learning activities'. Contemporary Educational Psychology 36 (4), pp. 257-267. https://doi.org/10.1016/j . cedpsych.2011.05.002.

Reinhold, S., Holzberger, D. and Seidel, T. (2018). 'Encouraging a career in science: a research review of secondary schools' effects on students' STEM orientation'. Studies in Science Education 54 (1), pp. 69-103. https://doi.org/10.1080/03057267.2018.1442900.

Renninger, K. A. and Bachrach, J. E. (2015). 'Studying triggers for interest and engagement using observational methods'. Educational Psychologist 50 (1), pp. 58-69. https://doi.org/10.1080/00461520.2014.999920.

Researchware Inc. (2013). HyperTranscribe 1.6.1.

Rifkin, W. D., Longnecker, N., Leach, J., Davis, L. and Orthia, L. (2010). 'Students publishing in new media: eight hypotheses - a house of cards?' International Journal of Innovation in Science and Mathematics Education 18 (1), pp. 43-54.

Saldaña, J. (2015). The coding manual for qualitative researchers. Sage.

Shirazi, S. (2017). 'Student experience of school science'. International Journal of Science Education 39 (14), pp. 1891-1912. https://doi.org/10.1080/09500693.2017.1356943.

Sinatra, G. M., Heddy, B. C. and Lombardi, D. (2015). 'The challenges of defining and measuring student engagement in science'. Educational Psychologist 50 (1), pp. 1-13. https://doi.org/10.1080/00461520.2014.1002924.

Smith, D., Schlaepfer, P., Major, K., Dyble, M., Page, A. E., Thompson, J., Chaudhary, N., Salali, G. D., Mace, R., Astete, L., Ngales, M., Vinicius, L. and Migliano, A. B. (2017). 'Cooperation and the evolution of hunter-gatherer storytelling'. Nature Communications 8 (1). https://doi.org/10.1038/s41467-017-02036-8.

Speed, C. J., Lucarelli, G. A. and Macaulay, J. O. (2018). 'Student produced videos - an innovative and creative approach to assessment'. International Journal of Higher Education 7 (4), p. 99. https://doi.org/10.5430/ijhe.v7n4p99.

Stocklmayer, S., Rennie, L. and Gilbert, J. K. (2010). 'The roles of the formal and informal sectors in the provision of effective science education'. Studies in Science Education 46 (1), pp. 1-44.

Tai, R. H., Liu, C. Q., Maltese, A. V. and Fan, X. (2006). 'Planning early for careers in science'. Science 312 (5777), pp. 1143-1144. https://doi.org/10.1126/science.1128690.

Thibaut, P. and Curwood, J. S. (2018). 'Multiliteracies in practice: integrating multimodal production across the curriculum'. Theory Into Practice 57 (1), pp. 48-55. https://doi .org/10.1080/00405841.2017.1392202. 
Tytler, R. and Osborne, J. (2012). 'Student attitudes and aspirations towards science'. In: Second international handbook of science education. Dordrecht, The Netherlands: Springer, pp. 597-625. https://doi.org/10.1007/978-1-4020-9041-7_41.

Venville, G., Rennie, L., Hanbury, C. and Longnecker, N. (2013). 'Scientists Reflect on Why They Chose to Study Science'. Research in Science Education 43 (6), pp. 2207-2233. https://doi .org/10.1007/s11165-013-9352-3.

Young, C. and Rasinski, T. V. (2013). 'Student-produced movies as a medium for literacy development'. The Reading Teacher 66 (8), pp. 670-675. https://doi.org/10.1002/trtr.1175.

Authors

How to cite

\section{Supplementary \\ material}

(C) The Author(s). This article is licensed under the terms of the Creative Commons Attribution - NonCommercial - NoDerivativeWorks 4.0 License. ISSN 1824-2049. Published by SISSA Medialab. jcom.sissa.it
Kaitlyn Martin is a doctoral candidate at the Centre for Science Communication at the University of Otago and recently was recognised with the Emerging Scientist Award at the New Zealand International Science Festival. She is an experienced science educator and communicator, and her research interests lie in improving engagement with science at the intersection of these two fields.

E-mail: kaitlyn.martin@postgrad.otago.ac.nz.

Lloyd S. Davis is an internationally recognised scientist, as well as an award-winning author and filmmaker. Currently the inaugural Stuart Professor of Science Communication at the University of Otago, he has authored 150 refereed publications on topics ranging from behavioural ecology to science communication and science diplomacy. E-mail: 1loyd.davis@otago.ac.nz.

Susan Sandretto is the Associate Dean of Academic Development at the College of Education at the University of Otago. Her research interests include multiliteracies, critical literacy, gender issues in education and practitioner research. I teach across the primary teacher education and education studies programmes and supervise at the postgraduate level. E-mail: susan.sandretto@otago.ac.nz.

Martin, K. M., Davis, L. S. and Sandretto, S. (2019). 'Students as storytellers: mobile-filmmaking to improve student engagement in school science'. JCOM 18 (05), A04. https:/ / doi.org/10.22323/2.18050204.

Available at https://doi.org/10.22323/2.18050204. 